


\section{HARVARD UNIVERSITY.}

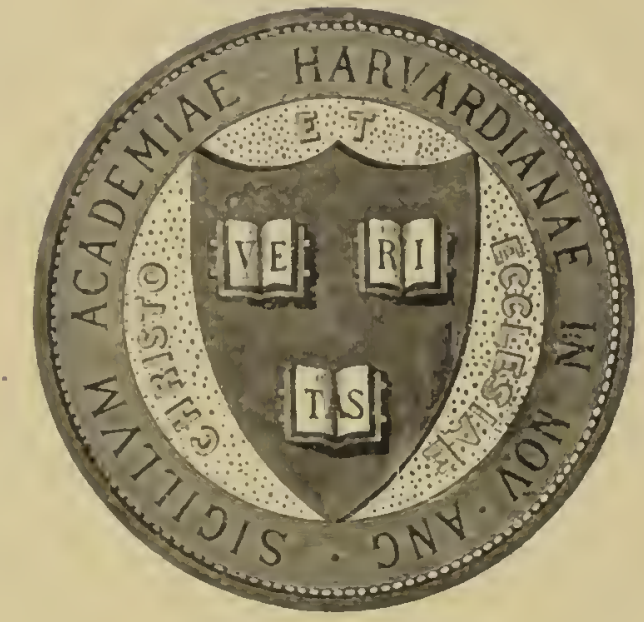

LIBRARY

(1) THE

MUSEUM OF.COMPARATIVE ZOÖLOGY 61.064

GIFT OF

$$
\text { Nathaw Banks }
$$

Februcing 14. 1923. 
$61.064 . \quad F E B \quad 11=1923$

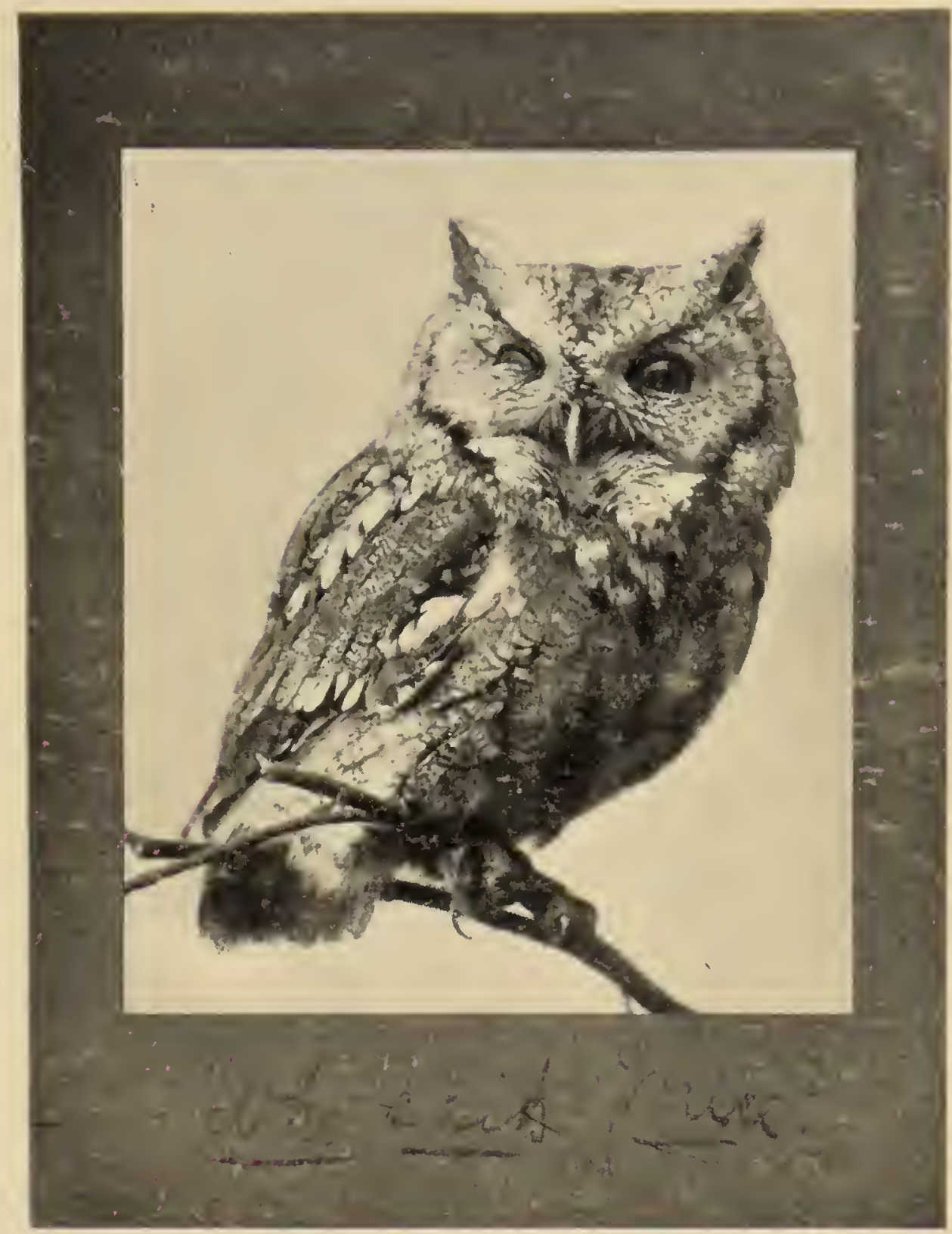

\section{THE MISSION OF THE BIRDSS}

By CLARENCE MOORES WEED

New Hampshire College Agricultural Experiment Station DURHA M

Nature Study Leaflet No. 2

April, 1902 


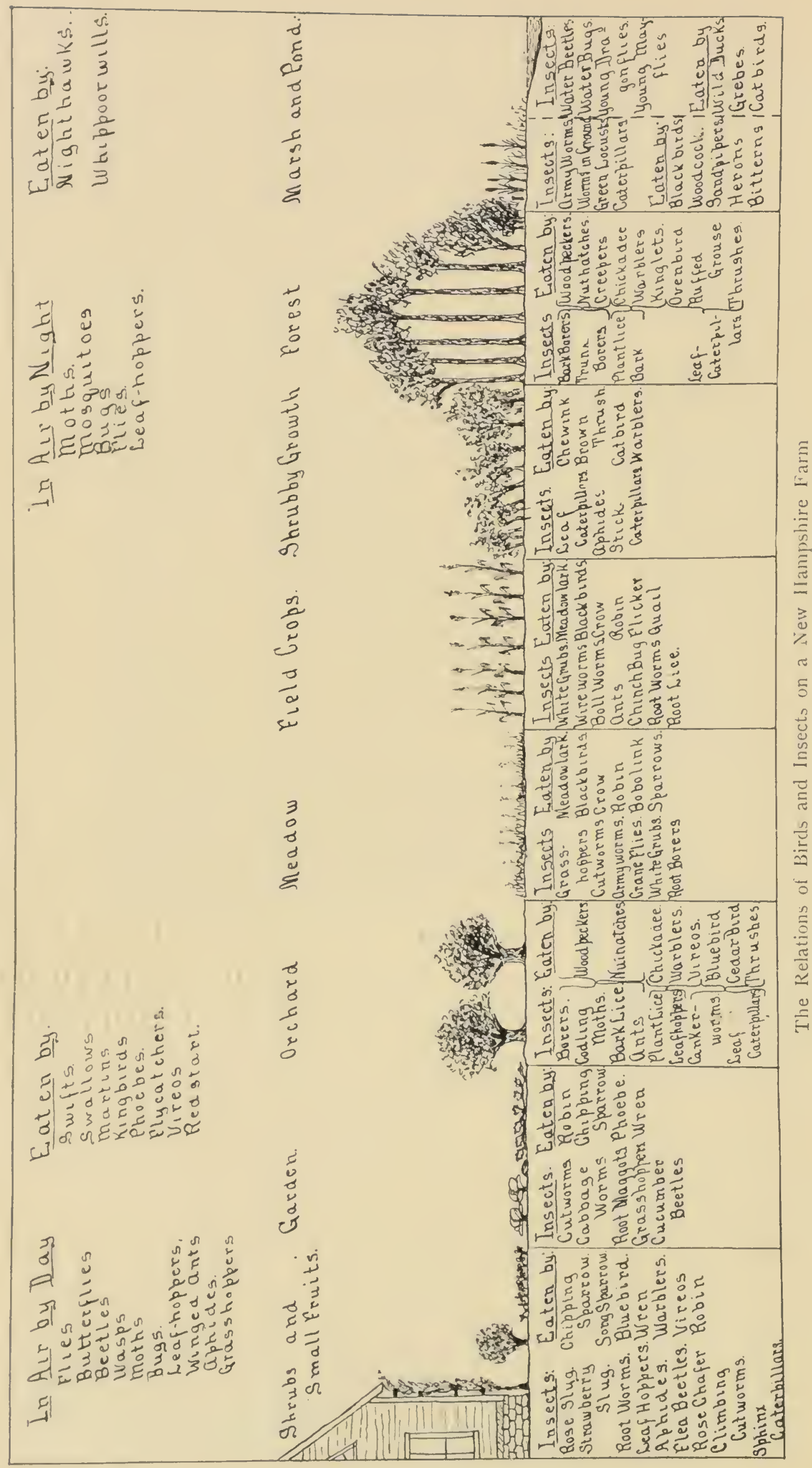




\title{
NATURE STUDIES
}

$\mathrm{FOR}$

\section{NEW HAMPSHIRE SCHOOLS}

No. 2

Spring, Summer, or Autumn

\section{THE MISSION OF THE BIRDS}

\author{
BY CLARENCE MOORES WEED
}

The living things in this world of ours are related to each other in numberless ways. In the last analysis animals depend upon plants for food, but to a very great extent this food supply is indirect, animals eating animals through varying degrees before the plant-feeding animal is reached. In a general way we may say that the world of birds obtains its food from the world of insects, for while some birds live wholly upon vegetation, and others wholly upon animals other than insects, the great majority of birds fincl among the insects their staple diet. It is the purpose of this leaflet to inclicate how close this relation is, and to show how it may be made an excellent topic for at least part of a term's work in spring or autumn in Nature Study in our New Hampshire schools in any grade above the fourth. The special relation between birds and seeds is reserved for a leaflet upon Winter Birds.

The topic should be developed through the observations of the children. Set aside if possible a part of the blacliboard for this purpose, drawing upon it such a slietchy outline of the diflerent parts of a New Hampshire farm as is shown on the opposite page. If blackboard space is not available make the sketch upon a large sheet of paper or cardboard fastened to the wall. Then ask the children to observe what sorts of insects are especially found in the diflerent situations, and also what birds they can see in the same places. As the observations are reported write llem in the proper place on the board so that after some weelis you shall get some such 
riagram as this. But do not copy this outline on the board: let the children make their or'n discoveries. When the topic is faily worked out. but not before, you might, if you choose, read to them the following paragraphs. Then drop the subject and take up something else.

\section{The Birds and the Insects}

One whose house is surrounded by lawns and shrubbery, with a garden near at hand, need not go out of doors in order to see evidence of the way in which the world of birds is set over against the world of insects to keep them in check. The robins on the lawn are searching for angle worms-which are not insects-and for cutworms, which are insects. "The chipping sparow and the wren in the shrubbery are always searching for insect food. The bluebird upon the post and the phobe upon the bare twig are on a similar quest.

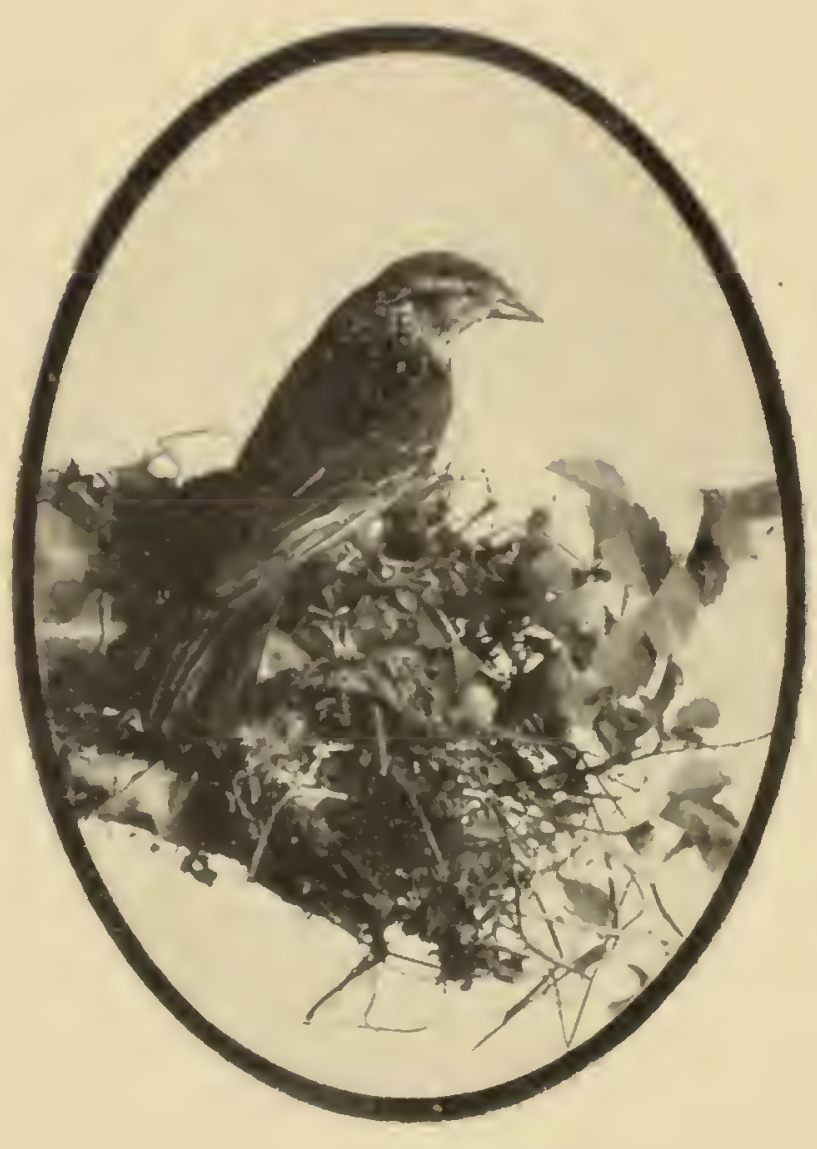

Fennale Red-winged Blackbisd while the warblers and the vireos darting through the foliage are after tiny insects.

'The hirds likewise watch over the orchard, feeding fieely upon the enemies of apple and other fruit trees. The trunlis of these trees are often attacked by horers which gnaw holes in the bark and wood. calusing the death of the trees. The woodpecliers are always al work humting for these borers and bringing them from their inding places hy means of their barbed tongues. On the outside of the bark of the trunk and branches the bark-lice and twig-hoppers are at work, and these are sought for by the muthatches. creepers, and chickatees. In winter also the bark is the hiding-place for the hibernating stages of many insects, like the plant-lice or aphides, which in summer feed upon the leaves. These are also deroured by the birds named. In a single day a 
chickadee will sometimes eat more than form humdied eggs of the apple plant-louse, while throughout the winter one will destroy an immense number of the eggs of the cankerworm, when these alle abundant. As soon in spring as the leaves begin to mofold they are attacked by the plant-lice that have survived the winter as well as by many sorts of caterpillars and other insects; the notorious cankerworm is one of the worst of these. But a host of biris come to the rescue of the trees; the aphicles are hunterl by the beautiful little warblers which go northward in early Mily, when aphicles are thick upon the unfolding leaves. The cankerworms and other similar leaf-eating caterpillars form the farorite food of many sorts of birds: Robins, catbirds, brown thrushes, bluebirds, warblers, vireos, cedarbirds, sparrows, orioles, and flycatchers all clevour them.

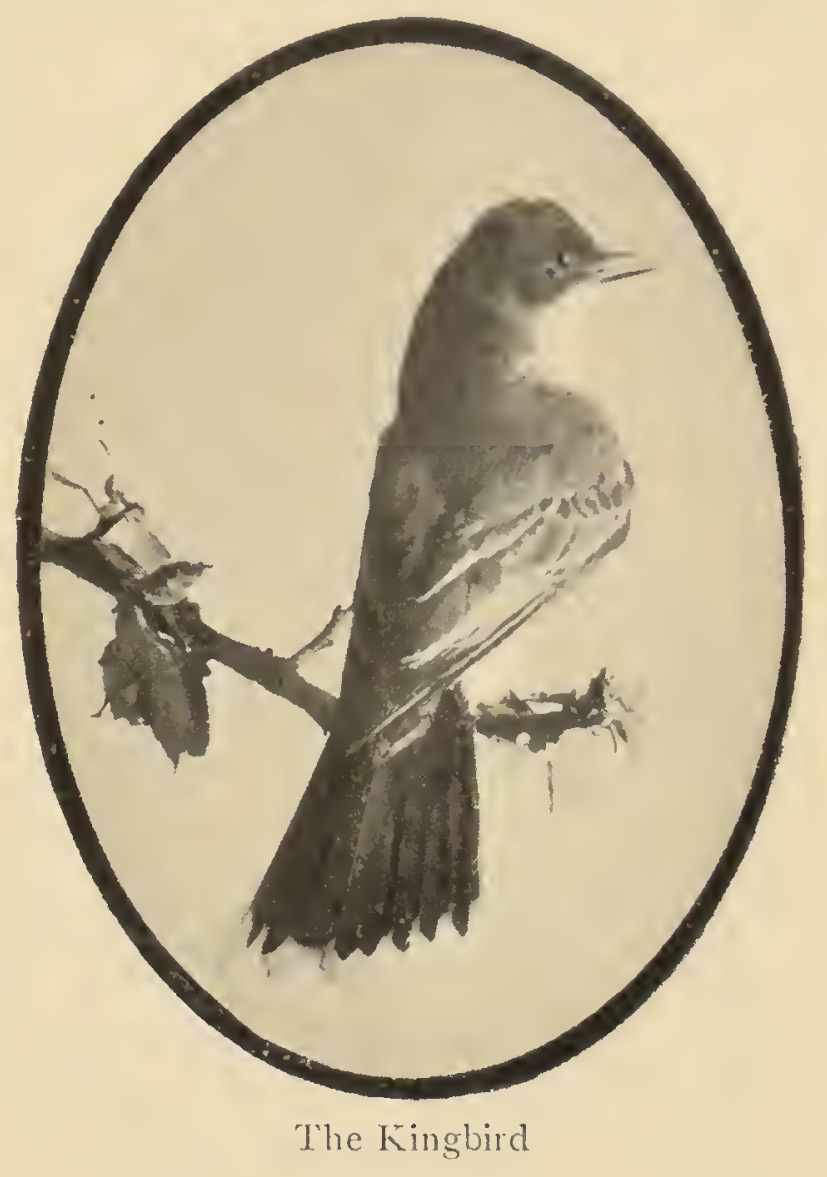

Passing now to the meadows we find a rather specialized condition as to insects. The grass plants are low-growing, and have a comparatively restricted set of enemies. These, however, are sufticiently numerous to destroy the crop) when not molested by their bird enemies. The roots of grasses are commonly attacked by white grubs - the destructive larva of the common Maty beetles or June bugs -as well as by wireworms-the larvie of the click bectles-and plant-lice or aphides which are fostered and cared for by various species of ants. The part of the plant just below the soil surface is sometimes attacked by meadow maggots-the peculiar larvat of the crane-flies and their allies-while various crown and root borers affect clover and timothy or herdsgrass. Just above the soil surface the fatal work of the cutworms and army worms is done, while still higher up the effect of the grasshoppers and chinch-bugs is likely to be seen.

Set over against these meadow pests we have the blackbircls, 
crows, robins, meadow larks, flickers, sparrows, and quail. Some of these birds have specialties in their meadow diet: in early spring the robin feeds very largely upon one of the smaller species of meadow maggots--the larve of the bibio fly; the flicker feeds more freely upon ants than upon any other insects; the bobwhite or quail is one of the comparatively few birds that seems to esteem the chinch bug as a source of food. The blackbirds and crows are fond of white grubs, while all these hirds and many others feed fieely upon army-worms, cutworms, and grasshoppers.

The condition in that part of the farm devoted to field crops is

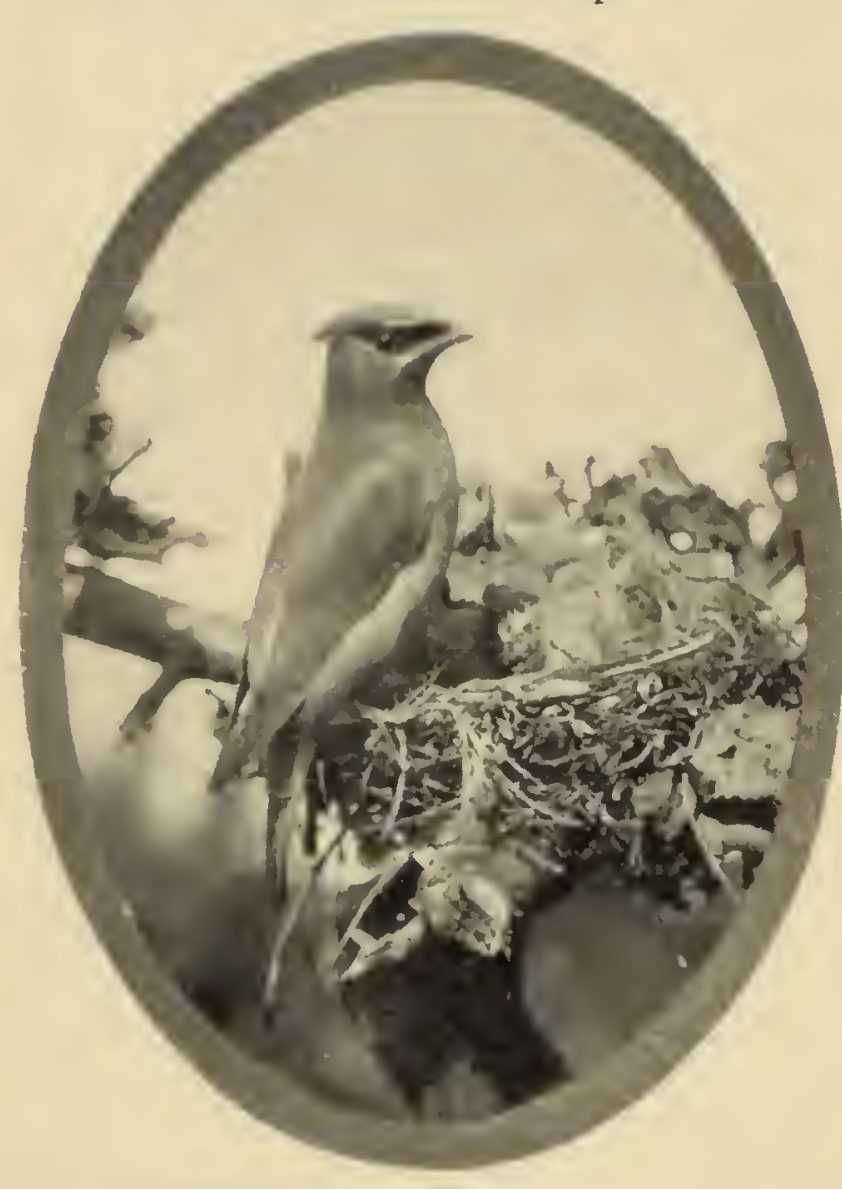

Plioto by Ned Deartiorn

Cedarbird at Ner: similar to that of the meadow. The insect pests are much the same and the birds that check them are very similar.

When we reach the shrubly growth along the border of the woods we come to a place where insect life is very abundant. The grassy growth scattered here and there in the more open spaces furnishes food for many sorts of insects, while the ground beneath the denser foliage is the hiding-place of many sorts that come from the bark and leaves above. The trunks and branches of the shrubs and small trees furnish subsistence to hordes of insects, while the leaves yield an abundant food to myrials of others. The most characteristic bird of these woodland horders is the chewink. or towhee bunting, often called the ground robin from its living so largely upon the ground beneath the shrubby growth, where it is continually searching for insect food. The brown thrasher frequents the same situation, gleaning food also among the twigs and leaves. The catbird is also commonly present, especially if a body of water is near at hand, in which case the Marrland yellow throat will also generally be found. 
And in the branches and among the leaves sparrows and wablers are abundant, ever searching for the tiny foes to plant-life.

The transition from the shrubly border of the forest to the forest proper is generally gradual, and there is more or less connection between the insect life as well as the bird life in the two areas. On the whole insects exist in the forest in less variety than in the shrubby growth or the open fields. As a rule there is little food for them on the ground beneath clense woods, so that their food supply is limited to the trees themselves. Upon these, however, they are very often destructively abundant. The bark is full of the burrows of various beetles, some species of which go deep into the trunk or larger branches, while the twigs and leaves are infested by many sorts of bark-lice, plant-lice and caterpillars. Of the leaf-feeding caterpillars, some go to the ground to pupate, and there they form an important part of the food of the ruffed grouse, which is one of the few birds that searches the soil surface in clense woods. The woodpeckers look after the bark and trunk borers, assisted more or less by the nuthatches and creepers; while the plant-lice and the leaf caterpillars are always in danger from the hungry beaks of the

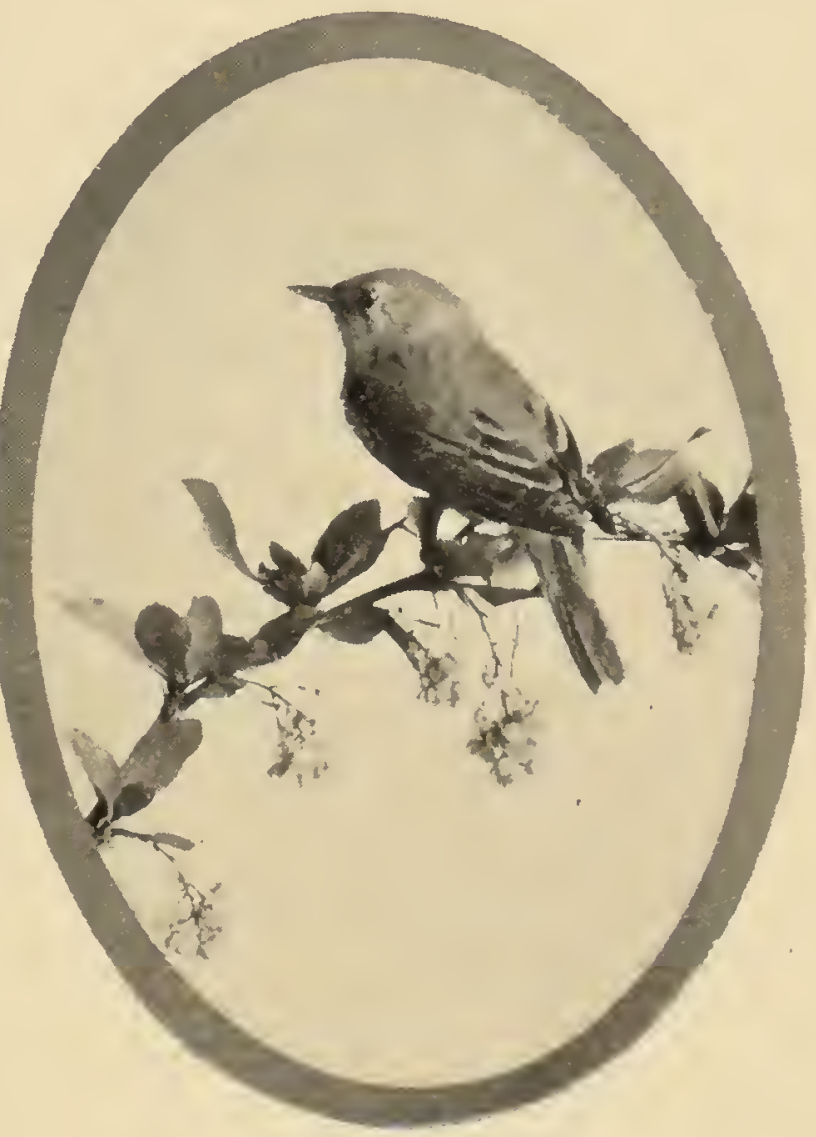

The Yellow I'arbler chickadees, kinglets, warblers, vireos, ovenbirds and thrushes.

Even the comparatively fer insects found in marshes, along the shores of ponds. and liring in the water itself are not free from bird attack. The blackbircls of various kinds, the numerous sparrows that live in lowlands, the snipe, woodcock, sandpipers, plovers, and rails, the herous and bitterns, the ducks, coots and grebes, all find in these insects part of their diet. 'The catbird malies a specialty of catching dragon flies just after they have emerged from their nymph stage, when they are waiting for the wings to harden before 
Hying away. Prof. F. H. Herrick has found that the young cathirds in the nests are fed freely with these solt-bodied dragon-flies. The Naryland rellow throat and the swamp-sparrow are especially likely to be seen in the region of rumning or standing water, getting much of their food from the insects fommd there.

Practically all of the insects that prey upon regetation exist in one stage of life as winged aclults which fly through the ar either during the dar or during the night. At such times they are liable to attack by certain hirds which patrol the air with great efficiency. liy day the general regions of the air are supervised by the swifts. swallows, and martins. Orer field, wood, orcharde meadow, halie. and pond these ärial police are constantly on the alert to check the careers of the evildoers. When the insects fly high the swallows are after them in the upper air; when they fly low the swallows skim the surface of soil and water to catch them. Flies and buttertlies, beetles and bugs, ants and aphides, grasshoppers and lealfhoppers, mosquitoes and moths. all fall rictims to these fowls of the ail.

But the birds just named are by no means the only watchers of the flying insects. The space near the trees and fences, the stumps and rocky clifts, is looked after by those birds which rest quietly on some perch nntil an insect comes near and then flies after it. With us the most important of these Hycatchers are the kinghird, the phobe. and the crested flycatcher, although the wood pewee and various other species also rencler efficient assistance. And even the space within the limits of the tree branches is looked after by the rireos and warblers, especially the redstart, the latter bird having well heen called "the flycatcher of the inner trectops."

A rery large proportion of the winged insects fly by night. But even then they are not exempt from destruction by birds. In the twilight as well as the deeper shades of night the night hawks and whipponwills are searching the air for insect food. Almost any winged insect, from the great Luma moth to the smaller flies, is liable to be talien by the capacious jaws of these silent messengers.

\section{The Hawks and Owls}

While insects are by far the most destructive animals with which the birds have to do, they are by no means the only ones. The great group of birrls of prey, of which the hawks and owls are the 
most familiar examples, serve a very useful purpose in keeping in check the mice and rats which otherwise would prove very troublesome. In some regions where the hawks and owls have been ruthlessly destroyed the damage from field mice las heen very great. The indiscriminate destruction of all sorts of hawks and owls simply because some hawks and ow!s catch poultry is a foolish and wasteful practice. As a matter of fact the smaller owls and the most common hawks feed upon mice and insects and seldom or never take poultry. For example, the little screech owl is perhaps our most common owl. Most people think it a privilege to shoot it on sight. But its food, as determined by those who have studied it long and carefulIy, consists chiefly of mice and insects. “A t night fall,, writes Dr. A. K. Fisher, "these bircls begin their rounds, inspecting the ricinity of farmhouses, barns, and corncribs, maling trips through the orchards and nurseries. gliding silently

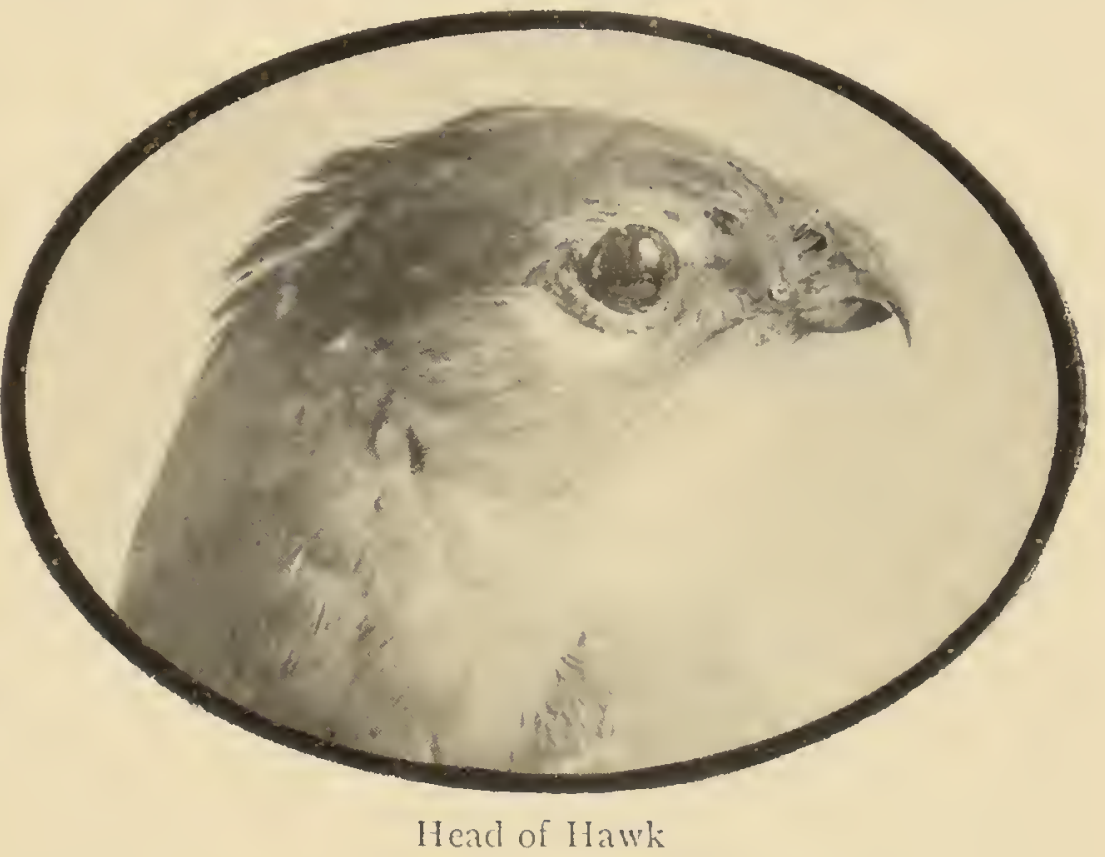
across the meadows or encircling the stacks of grain in search of mice and insects. Thousands upon thousands of mice of clifierent kinds thus fall victims to their industry. Their economic relations are therefore of the greatest importance, particularly on account of the abundance of the species in many farming districts, and whoever destroys them through ignorince or prejudice should be severely condemmed."

"Those who have rambled much in the comntry in the clear winter mornings must have noticed the traclis of mice which often form networlis in the snow, crossing and recrossing. passing in and out of walls and stacks, or converging towarl some choice bit of food-all tending to show how active these litule rodents are during the night, a period when most of the world sleeps. Occasionally a track stops abruptly, and while the olsserver is trying to real 
more of the history written in the snow, his eyes catch the faint impression of a pair of wing-tips near where the trail ends, and instantly he recognizes that a tragedy has been enacted."

The commoner hawks are also beneficial, destroying great numbers of mice and insects. It is all right to trap or shoot a hawk or owl that is known to rob the poultry yard, but it is a mistake to destroy all sorts of these birds incliscriminately.

\section{Adaptation of Structure to Functions}

It would be a pity to make this study of the relation of birds to insects and other animals without calling attention at the same time to the alaptation of the structure of each bird to the feeding habits which so largely determine its mode of life. There is not space here for the full discussion of this subject I should like to give, but a few lines of ohservation may be briefly indicated.

The bird talies its fool with or in its bealk: Notice the strong,

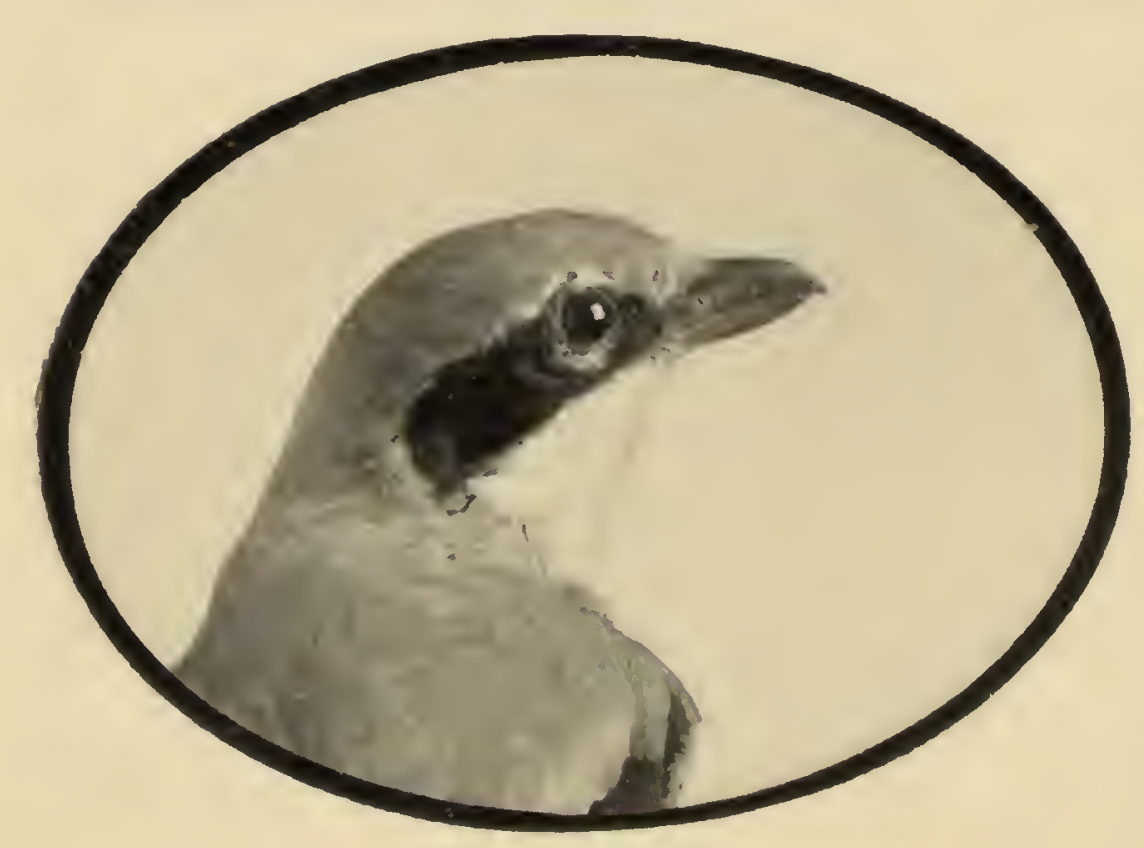

Head of -hritie solicl beak of the robin, the crow, and other bircls that get fool on the ground; the chisel-like beak of the woodpeckers; the very wide beak of the sivallows, the night hawk, and the whippoorwill; the flat beak of the flycatchers; the pointed beak of the warblers; the long, probing beal of the woodcock. plovers, and sandpipers; the spearlike beak of the herons and bitterns; the wide, flat beak of the duclis, and the hooked beak of the hawks and owls. Each of these is well adapted to getting the sort of food the bird requires.

The manner and habits of flight of the bird are largely determined by the nature of its food: Notice the comparatively labored flight of the robin, crow, and other birds with large bodies; the quick, undulatory motion of the woodpecliers; the short, strong flights of the flycatchers; the easy, light-bodied flight of the swal- 
lows, night hawk, and whippoorwill; the restless motion of the warblers; and the lazy soaring of the havks. See how the relation of wings to body in every case is adapted to the feeding habits of the bird.

And in like manner the legs and feet are adapted to the mode of life: Notice the strong legs and well-developed toes of the birds that live on the ground in fields and mearlows; the peculiar feet of the woolpecliers with which they climb rertical surfaces; the long legs of the plovers and sandpipers, the herons and bitterns; the webbed feet of the clucks, and the tearing talons of the birds of prey.

In the study of these adaptations let the children see for themselves, and let them all work out in their own minds the adaptation of structure to function. For in all our nature study our chief privilege is to lead the children to sec and to sec why. 'The importance of a bit of truth is greatly increased when we are abic to see its relations to other bits of truth.

\section{Helps to the Study of Birds}

Books about birds are very numerous, although there is none as yet published which deals specifically with their economic relations. Every teacher who attempts to do anything with bird study for her pupils should have upon her desk some illustrated guide to our common birds. The one that is likely to be most useful is Chapman's "Bird Life," with colored plates, published by D. Appleton \& Co. at \$2.00. School authorities should provide one of these books for each desk where nature study is to be taught. Herrick's "Home Life of Wild Bircls" (Putnams, \$2.50), will also be especially helpful in leading to the observations of the nesting habits. The books of Bradford Torrey and Frank Bolles (Houghton, MifHin \& Co.), as well as of Schuyler Mathervs (D. Appleton \& Co.), deal very largely with the birds of New Hampshire, and consequently are of special value for use in our state.

\section{The Lesson in It All}

The study thus outlined of the Mission of the Birds will have failed to accomplish its most important results if the pupils do not get from it a greater respect for the world of birds, a deeper interest in their welfare, and a larger sense of the mity of that world of liv- 
ing things of which man is the highest example. A discussion of the methods of encouraging useful birds should follow as a natural consequence of the study, - and this should lead to the erection of bird houses, the planting of Russian mulberry or other trees to furnish food for the birds, and especially to checking the wanton destruction of bird life.

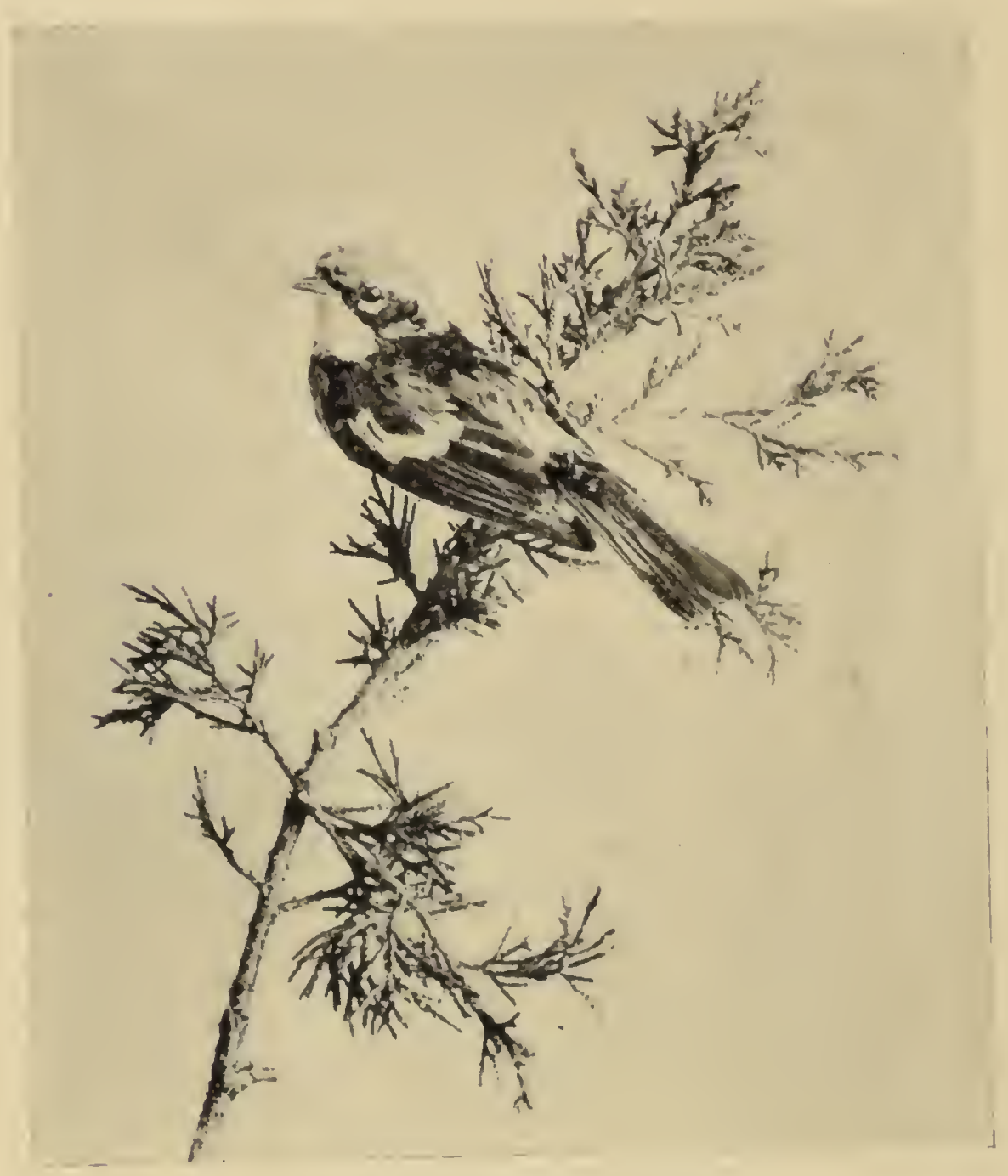

The Blackburnian Warbler. 
use, N. Y.

use, N.
A4 21,1908 


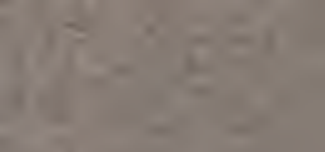

$$
-2=
$$

$=3 x \quad$ al

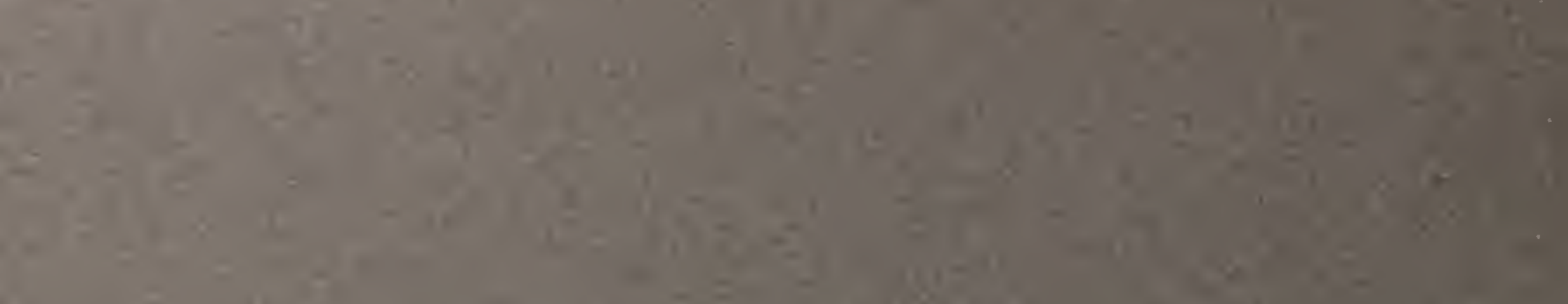
$\frac{1}{2}$

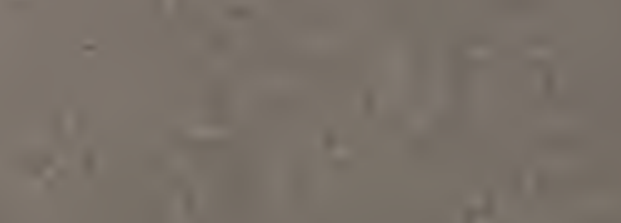

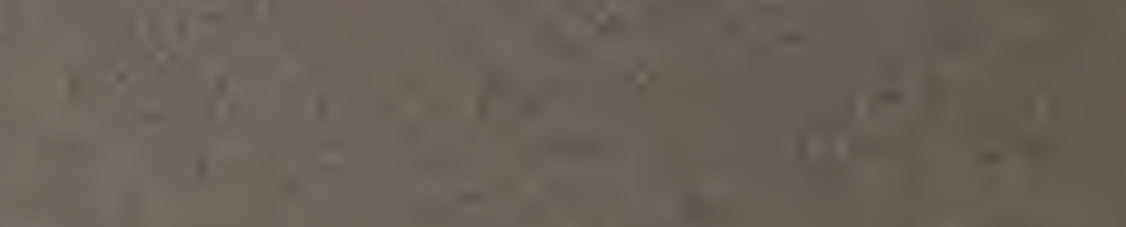
$x^{2}$ 6.8:

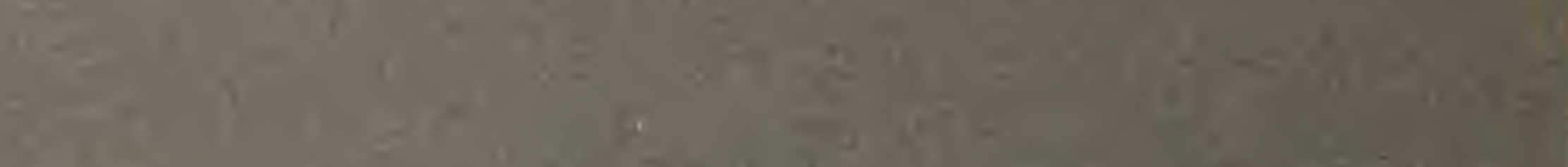

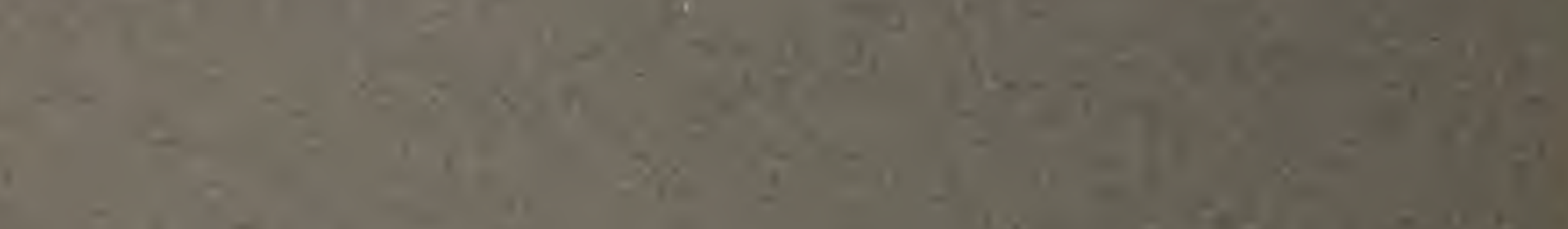

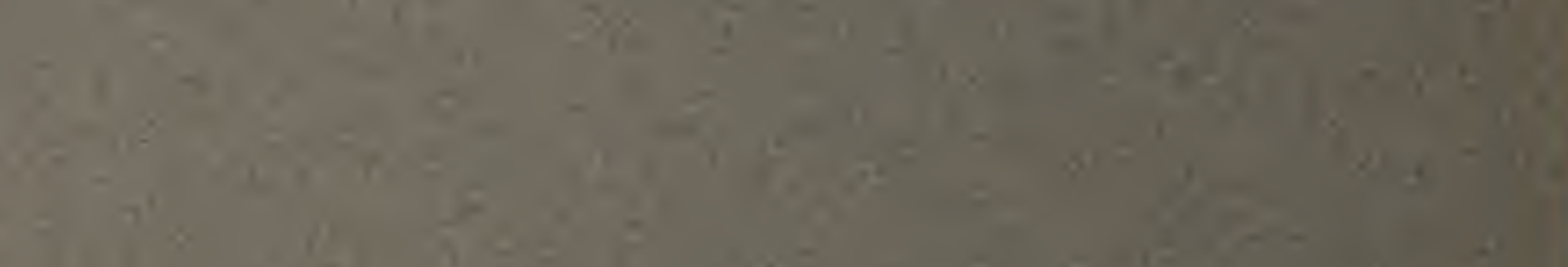

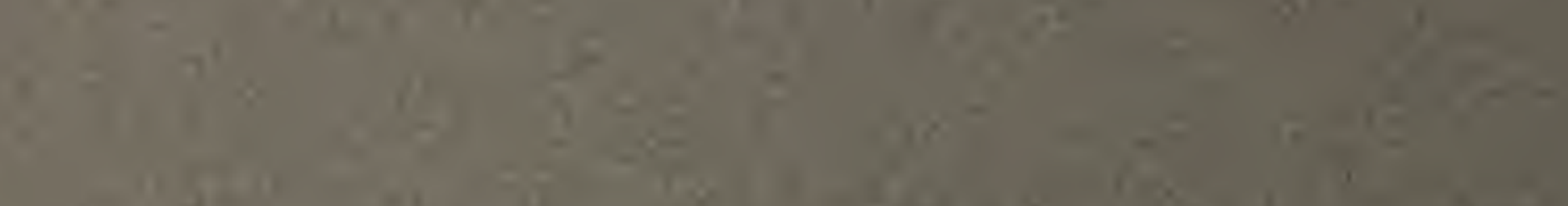

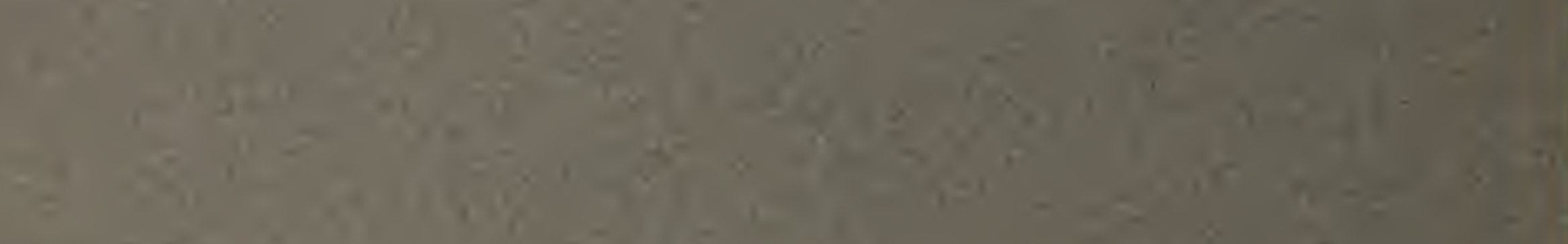

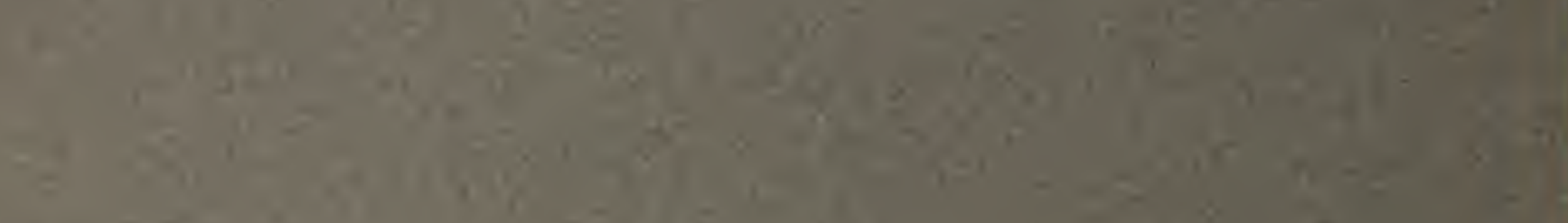
.

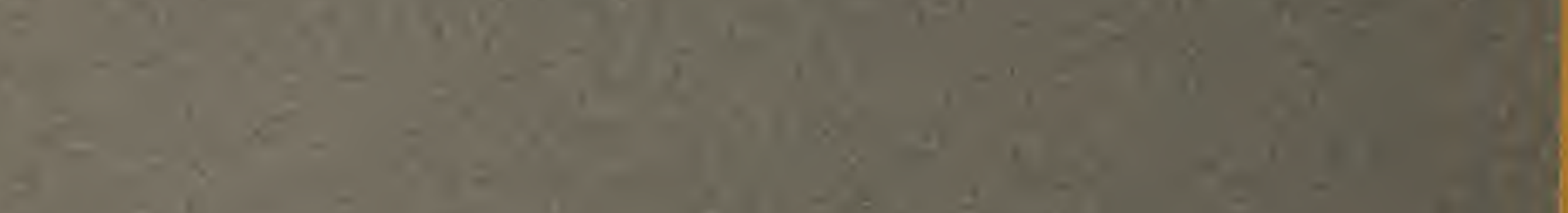

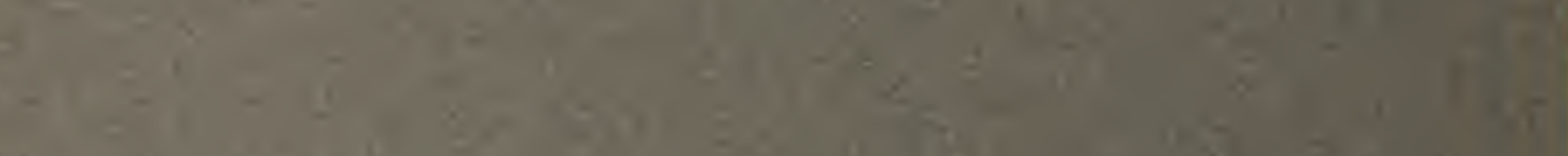

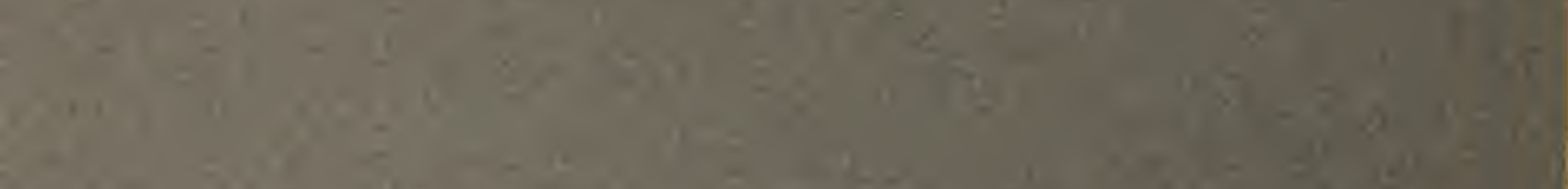

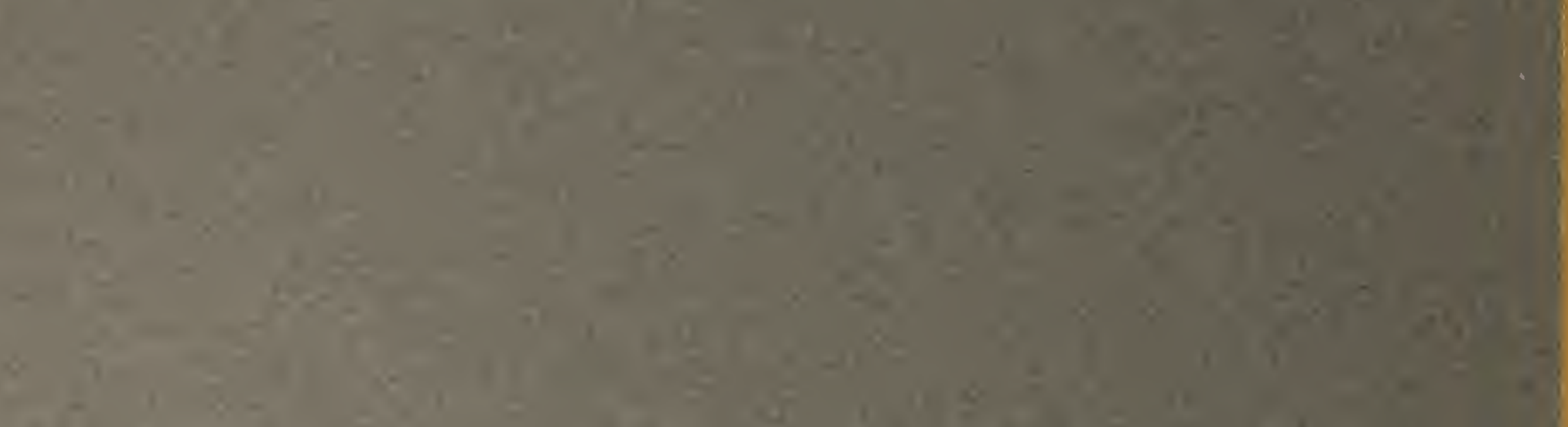

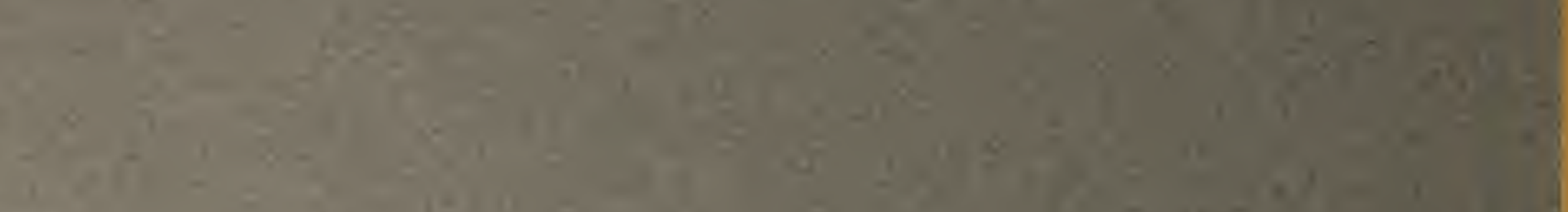

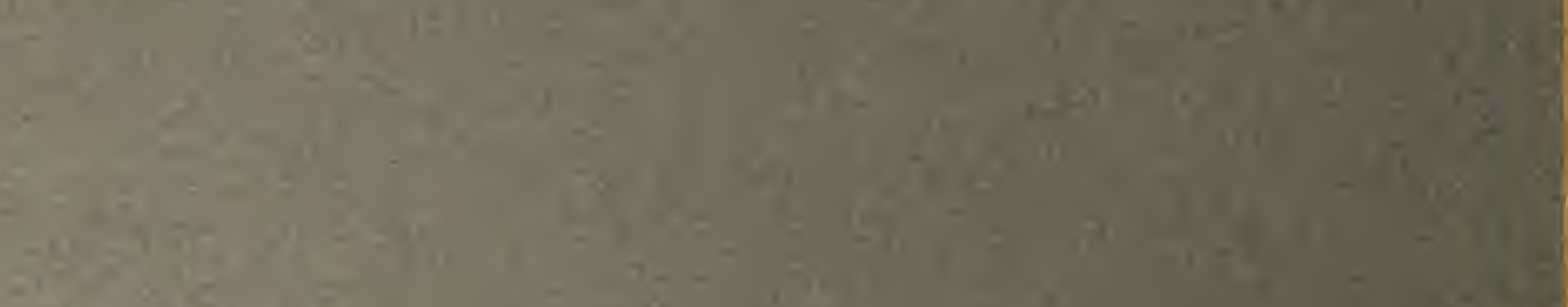

